\title{
Phylogenetic Evidence that Two Submerged-Habitat Fungal Species, Speiropsis pedatospora and Xylomyces chlamydosporus, Belong to the Order Jahnulales Insertae Sedis Dothideomycetes
}

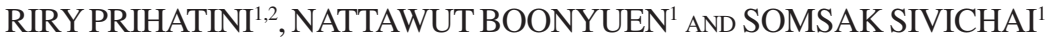 \\ ${ }^{1}$ BIOTEC National Centerfor Genetic Engineering and Biotechnology, Thailand Science Park, 113 Paholyothin Road, \\ Klong 1, Klong Luang, Pathumthani, 12120 Thailand; \\ ${ }_{2}^{2}$ Balai Penelitian Tanaman Buah Tropika, Jalan Raya Solok-Aripan Km.8, Solok 27301, Sumatera Barat, Indonesia
}

\begin{abstract}
The genera Speiropsis and Xylomyces are anomorph fungi. The taxonomic address for the fungi has been unclear. In this study, observation of morphological traits indicates that they have a unique pattern of mycelia with dark-brown to black colour and thick-walled hyphae. The same culture patterns of certain fungi isolated from freshwater habitats in Thailand were selected from BIOTEC Culture Collection (BCC, Thailand), while more species were added from Centraalbureau voor Schimmelcultures (CBS, Netherlands). These fungi were composed of Jahnula spp. (2-celled ascospores), Brachiosphaera tropicalis (hyaline and 4-5 armed conidia), S. pedatospora (hyaline and branches conidia) and Xylomyces sp. (dematiaceous and fusiform chlamydospores). This study was undertaken to confirm the taxonomic address for S. pedatospora and Xylomyces based on phylogenetics relationships as inferred from their ITS rDNA sequence data by using MP (unweighted and successive weighted MP), NJ, ML and Bayesian analysis. Phylogenic analysis revealed that isolates of $S$. pedatospora (2 strains) was a member of the Order Jahnulales and clustered with Jahnula spp. (5 strains) and B. tropicalis (4 strains) with $>82 \%$ bootstrap support and $100 \%$ posterior probabilities. Four isolates of X. chlamydosporus, X. elegans and X. aquaticus were shown to be polyphyletic within the Jahnulales and Pleoporales. The MP and NJ showed the same topology as in the Jahnulales clade obtained by ML analysis.
\end{abstract}

Key words: ITS rDNA, Speiropsis pedatospora, Xylomyces

The genus Speiropsis are possessed with erect, simple, straight, septate, mononematous, aggregates in fascicles or synnematous to sporodochial conidiophores with discrete, denticulate, polyblastic conidiogenous cells and catenate conidia in branched or unbranched chains (Barbosa and Gusmao 2005). S. pedatospora is a mitosporic fungus found in submerged leaves in freshwater bodies (Barbosa and Gusmao 2005) and also a leaf pathogen in Eucalyptus saligna.

Additionally, the genus Xylomyces a mitosporic fungus, has different nodes of ontogeny which produces large, dematiaceous, thick-walled, multiseptate and fusiform chlamydospores. This anamorph fungus is mainly found in freshwater-submerged-wood (Goh et al. 1997). The taxonomic position of Xylomyces and S. pedatospora are still unclear.

Furthermore, Brachiosphaera, another freshwater fungus, characterized by producing round-shaped conidia with conidial arms, mostly 4-5 each with 1-4 septa. Its colonies are characterized by effuse, septate mycelia, mostly submerged in culture media. Initially it is hyaline and turns into olivaceous brown when older. A few segments of hyphae become slightly constricted at the septa, and cells are enlarged, with ellipsoidal to round conidia in their clustering (Chang 1994).

All Jahnula sp., a group of fungi that inhabit wood submerged in freshwater, are characterized by hyaline to blackish-translucent-membranous ascomata with subtending, wide-septate-brown-spreading hyphae, large angular cells of peridia, septate pseudoparaphyses, hamathecium, eight-

*Corresponding author, Phone: +62-755-20137, Fax: +62-755-20592, E-mail: riri_silva@yahoo.com spored, clavate to cylindrical asci, one-septate, broad fusiform, brown and multiguttulate ascospores. Moreover, Jahnula colonies on potato dextrose agar (PDA) grew slowly having dark-brown to black, effuse hyphae which are thickwalled, septate, constricted at the septa and cells of the hyphae are cylindrical to subglobose (Raja and Shearer 2006). These cultural traits of Jahnula spp. were similar to Xylomyces sp., S. pedatospora and Brachiosphaera tropicalis (Boonyuen and Sivichai, personal observation).

Based on those similarities, these fungi were suspected to have same taxonomic address. Since Jahnula sp. and $B$. tropicalis. were in order Jahnulales (Campbell et al. 2007), the same order was suspected to be the taxonomic address for S. pedatospora and Xylomyces sp. However, the limited of morphological traits of these fungi made it impossible to determine if they belonged to the same order. The molecular phylogenetics approach therefore offers the opportunity to elucidate the taxonomic position of these fungi.

The two objectives of this study are: (i) to address the taxonomic position of S. pedatospora and Xylomyces sp. based on ITS sequence data and (ii) to compare the phylogenic topologies of the order Jahnulales calculated on the Maximum Parsimony, Distance Matrix method and Maximum Likelihood analysis.

\section{MATERIALS AND METHODS}

Fungal Isolates. We studied a total 15 strains obtained from the BIOTEC Culture Collection (BCC, Thailand) and the Centraalbureau voor Schimmelcultures (CBS, Netherlands). All strains were maintained on PDA. Approximately $100 \mathrm{mg}$ of mycelium was used for each DNA extraction. 
DNA Extraction. Fungal mycelium was harvested to the $10 \mathrm{ml}$ tubes and added by sterile sand with 300 il $0.5 \mathrm{~N} \mathrm{NaOH}$ and griund into a fine powder. The harvested tubes were centrifuged at $11000 \mathrm{~g}$ for $3 \mathrm{~min}$. Then $5 \mathrm{il} \mathrm{supernatant} \mathrm{was}$ dissolved in $195 \mu \mathrm{l}$ Tris $\mathrm{HCl} \mathrm{pH}$ 8.0. These samples were used directly as templates in PCR (modified from Wang et al. 1993).

DNA Amplification, Purification and Sequencing. The ITS region (ITS1, 5.8S and ITS2) was amplified using the pair of primers ITS 1 and ITS4 (White et al. 1990). A single $50 \mu \mathrm{l}$ PCR reaction contained: $34 \mu \mathrm{l}$ sterile water, $5 \mu 110$ times PCR

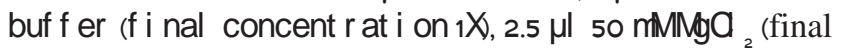
concentration $2.5 \mathrm{mM}$ ), $1 \mu \mathrm{l} 10 \mathrm{mM}$ dNTP mix (final concentration $0.2 \mathrm{mM}$ ), $1 \mu \mathrm{l} 10 \mu \mathrm{M}$ each of the primers (final concentration $0.2 \mu \mathrm{l}$ ), $0.5 \mu \mathrm{l}$ Taq polymerase and $4 \mu \mathrm{l}$ DNA template. The PCR thermal cycling profile for the primer ITS 1 and ITS 4 included a first denaturation step at $94^{\circ} \mathrm{C}$ for $2 \mathrm{~min}, 35$ cycles of $94^{\circ} \mathrm{C}$ for $1 \mathrm{~min}, 55^{\circ} \mathrm{C}$ for $1 \mathrm{~min}, 72^{\circ} \mathrm{C}$ for $1 \mathrm{~min}$, and final extension step at $72^{\circ} \mathrm{C}$ for $2 \mathrm{~min}$. Analysis of the PCR products were performed on a $0.8 \%$ agarose gels stained with ethidium bromide under a $1000 \mathrm{v}$ illuminator. The PCR products were purified using Nucleosprin Plant DNA Purification Kit (Macherey-Nagel). Sequencing of the amplified purified PCR product was performed by the BIOTEC Research Unit (BSU). The sequences were then submited to Genbank (www.ncbi.com) to obtain genbank accession numbers.

Phylogenetics Analysis. Multiple alignments were performed on the sequences generated in this study with those obtained from GenBank (shown with GenBank accession numbers) using the Clustal W1.6 incorporated in BioEdit (http://www.mbio.ncsu.edu/BioEdit/bioedit.html). The sequences were adjusted manually to minimize the gap. The data set was exported as a nexus file for maximum parsimony, maximum likelihood and distance matrix method analyses in PAUP 4.0b10 (Swofford 2002). The phylogenetic trees were generated using optimality criteria: maximum parsimony (MP), distance matrix method (Neighbor Joining/ $\mathrm{NJ}$ ), and maximum likelihood (ML) to generate trees with robust support.

Maximum parsimony analyses were performed by using heuristic methods with the character first defined as unordered and given equal weighting. Successive weighted parsimony was executed to select the more consistent characters. Relative support for resulting trees was obtained from bootstrap analysis using 1000 heuristic searches by taking a $50 \%$ or greater frequency in the consensus trees. All heuristic searches were performed by tree-bisectionreconstruction branch swapping with 100 random sequences. Successive weighting was performed to ensure the stability of the weight and to evaluate the consistency of the characters. Successive weighting was performed based on the maximum value of the rescaled consistency index for each character for all most parsimonious trees (Farris 1989). The robustness test of the each branch was calculated by the consistency index $(\mathrm{CI})$, retention index (RI), rescaled consistency index (RC) and homoplasy index (HI). The Kishino-Hasegawa test (KHT) was performed in order to determine the best tree fit (Kishino and Hasegawa 1989).
Anisomeridium polyori and Pyrenula pseudobufonia were used as the out-group.

An evolutionary model was constructed by using the Modeltest 3.06 (Posada and Crandall 1998). Bayesian posterior probabilities were determined by the Markov Chain Monte Carlo sampling in MrBayes 3.0b4 (Huelsanbeck and Ronqvist 2001), using an estimated model of evolution. Markov chains were run for $2 \mathrm{~m}$ generation and trees were sampled every $100^{\text {th }}$ generation (resulting 20000 total trees). The first 2000 trees were used for the burn in phase of the analyses and were discarded. The remaining 18000 (postburning) trees were used to generate a majority-rule consensus tree.

Sequences used for phylogenetic analysis (accession numbers in parentheses): Aliquandostipitate khaoyaensis (AF201728), Jahnula sunyatsenii (AF201727), Capnodium coffea (DQ491515), Capnodium salicinum (AJ244240), Dothidea hippophaeos (AF027763), D. sambuci (DQ491505), D. insculpta (AF027763), Westerdykella dispersa (DQ468031), W. cylindrical (AY943056), Elsinoe ampelina (AY826764), E. proteae (AF097578), Mycosphaerella fijiensis (EF666077), M. graminicola (DQ019341), M. punctiformis (AY152594), Alternaria alternate (EF192234), Pyrenophora phaeocom (DQ491507), Setosphaeria rostrata (AF071342), Leptosphaeria maculans (DQ133891), L. biglobosa (DQ133893), Lophiostoma arundinis (AJ496633), A. polypori (DQ782838), P. pseudobufonia (DQ782845).

\section{RESULTS}

Sequences partial 18S, ITS1 and ITS2 regions were aligned along with the intervening 5.8S rDNA and partial $28 \mathrm{~S}$ regions. The average size of this region was $495 \mathrm{bp}$, of which the shortest sequence was $X$. acuaticus CBS636.91 (465 bp) and the longest was Jahnula sp. SS3792 (536 bp). The partial $18 \mathrm{~S}$ region ranged from 5 to $49 \mathrm{bp}$, ITS1 region from 137 to $172 \mathrm{bp}$, ITS2 region from 160 to $189 \mathrm{bp}$, partial $28 \mathrm{~S}$ region from 5 to $8 \mathrm{bp}$, while 5.8 region was conserved (156 bp). Overall, S. pedatospora displayed a sequence of 486 to 487 bp, Xylomyces sp. 465 to 502 bp, B. tropicalis 485 to 488 bp, Jahnula sp. 487 to 536 bp, and T. aristata 487 bp. The gene position of 15 new sequences generated in this study are presented in Table 1 . The matrix was process to produce phylogenies based on MP (Fig 1), NJ (Fig 2) and ML (Fig 3).

\section{DISCUSSION}

The phylogenies were placed within the Dothideomycetes, which is based on A. polypori and P. pseudobufonia (both species belong to the Pyrenulales, Eurotiomycetes). Two strains of S. pedatospora and X. chlamydosporus were placed in the Jahnulales, together with all strains of B. tropicalis and Jahnula sp. Meanwhile, other strains, including $X$. elegans, $X$. aquaticus and T. aristata were clade in Pleosporales.

The order Jahnulales, Dothideomycetes was introduced by Pang et al. (2002), characterized by stalked/sessile, dimorphic ascomata, hyphal-stalk-cell of approximately 
Table 1 Gene position in nuclear partial 18S, ITS 1, 2 regions, 5.8 rDNA, and partial 28S rDNA sequence

\begin{tabular}{|c|c|c|c|c|c|c|c|}
\hline \multirow{2}{*}{ Fungal species } & \multirow{2}{*}{ Accession no. } & \multirow{2}{*}{$\begin{array}{c}\text { Sequence } \\
\text { length (bp) }\end{array}$} & \multirow{2}{*}{$\begin{array}{c}\text { Partial } \\
18 \mathrm{~S}\end{array}$} & \multicolumn{4}{|c|}{ Position of each region on the sequence } \\
\hline & & & & ITS1 & $5.8 \mathrm{~S}$ & ITS2 & Partial 28S \\
\hline Jahnula appendiculata SS3028 & FJ887914 & 511 & $1-5$ & $6-161$ & $162-317$ & $318-506$ & $507-511$ \\
\hline Jahnula australiensis SS3613 & FJ887915 & 487 & $1-5$ & 6-158 & $159-314$ & $315-482$ & $483-487$ \\
\hline Jahnula sp. SS3792 & FJ887916 & 536 & $1-49$ & $50-186$ & $187-342$ & $343-531$ & $532-536$ \\
\hline Jahnula granulosa SS3815 & FJ887917 & 523 & $1-5$ & $6-177$ & $178-333$ & $334-518$ & $519-523$ \\
\hline Xylomyces chlamydosporus SS0807 & FJ887918 & 502 & $1-5$ & $6-162$ & $163-318$ & $319-497$ & $498-502$ \\
\hline Xylomyces chlamydosporus SS2917 & FJ887919 & 497 & $1-5$ & $6-159$ & $160-315$ & $316-492$ & $493-497$ \\
\hline Xylomyces elegans SS1077 & FJ887920 & 494 & $1-5$ & $6-145$ & $146-301$ & $302-476$ & $477-494$ \\
\hline Xylomyces aquaticus CBS636.91 & FJ887921 & 465 & $1-5$ & $6-144$ & $145-300$ & $301-460$ & $461-465$ \\
\hline Brachiosphaera tropicalis SS2522 & FJ887922 & 485 & $1-5$ & $6-156$ & $157-312$ & $313-480$ & $481-485$ \\
\hline Brachiosphaera tropicalis SS2523 & FJ887923 & 488 & $1-5$ & $6-159$ & $160-315$ & $316-483$ & $484-488$ \\
\hline Brachiosphaera tropicalis SS2724 & FJ887924 & 487 & $1-5$ & $6-158$ & $159-314$ & $315-482$ & $483-487$ \\
\hline Brachiosphaera tropicalis SS2944 & FJ887925 & 486 & $1-5$ & $6-157$ & $158-313$ & $314-481$ & $482-486$ \\
\hline Speiropsis pedatospora SS2229 & FJ887926 & 487 & $1-5$ & $6-158$ & $159-314$ & $315-482$ & $483-487$ \\
\hline Speiropsis pedatospora SS2236 & FJ887927 & 486 & $1-5$ & $6-157$ & $158-313$ & $314-481$ & $482-486$ \\
\hline Tetraploa aristata CBS996.70 & FJ887928 & 487 & $1-5$ & $6-166$ & $167-322$ & $323-482$ & $483-487$ \\
\hline
\end{tabular}

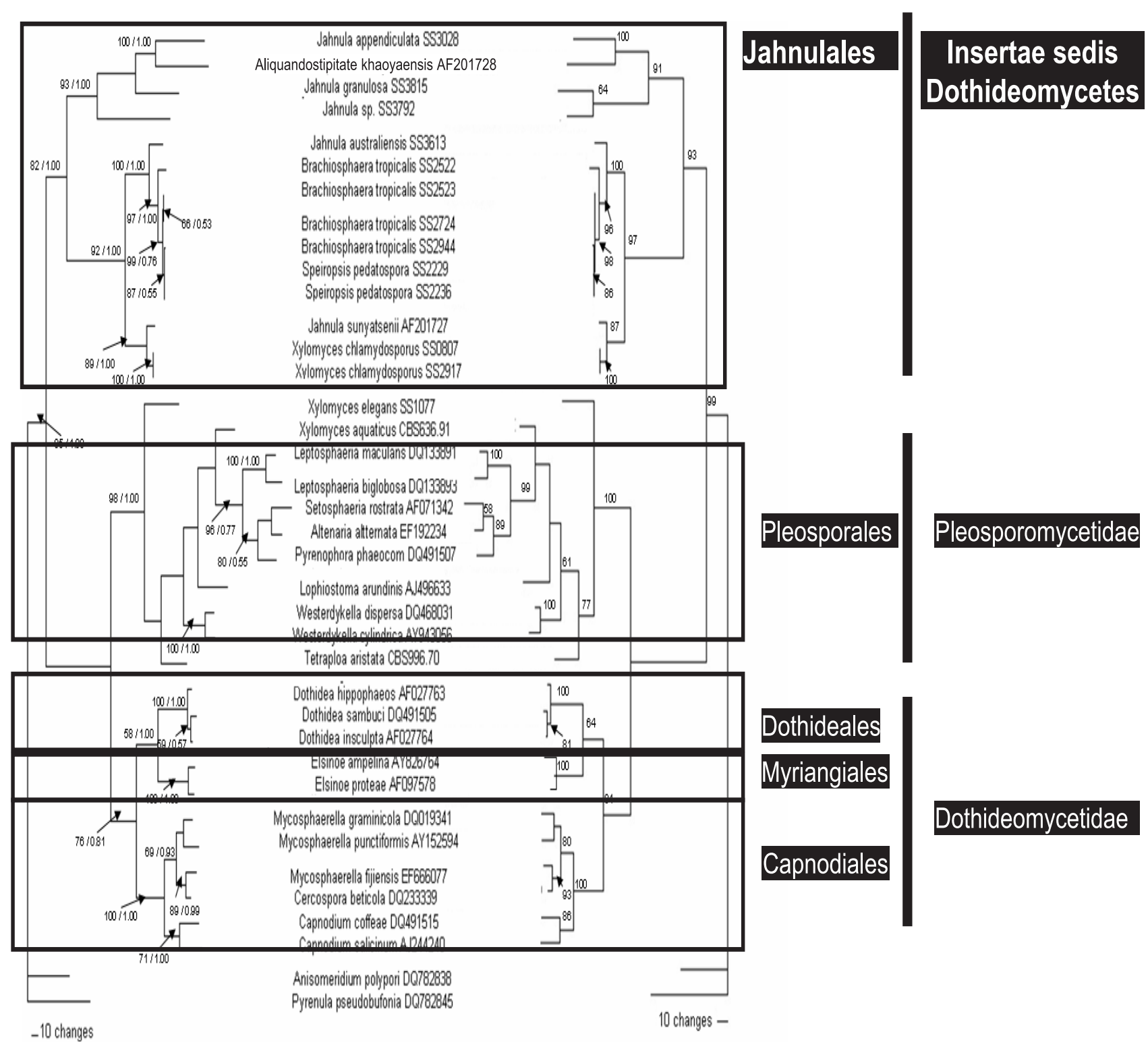

Fig 1 Phylogenetics relationship of Speiropsis pedatospora, Xylomyces spp., Brachiosphaera tropicalis and Jahnula spp. based on ITS and 5.8S rDNA sequences. The phylogram represented were the best trees obtain from Kishino-Hasegawa Test in PAUP* $4 \mathrm{~b} 10$ based on unweighted parsimony (left) and successive weighted parsimony (right). Bootstrap support $>50 \%$ for both trees were shown above the branches. Posterior probabilities were demonstrated above the branches of unweighted parsimony tree after the bootstrap values. The unweighted parsimony yielded 2 MPTs with 2204 steps, $\mathrm{CI}=0.468, \mathrm{RI}=0.667, \mathrm{RC}=0.312$ and $\mathrm{HI}=0.532$. The successive weighted parsimony analysis yielded a phylogeny with 1031 steps, $\mathrm{CI}=0.564$, RI $=0.712, \mathrm{RC}=0.402$ and $\mathrm{HI} 0.436$. 


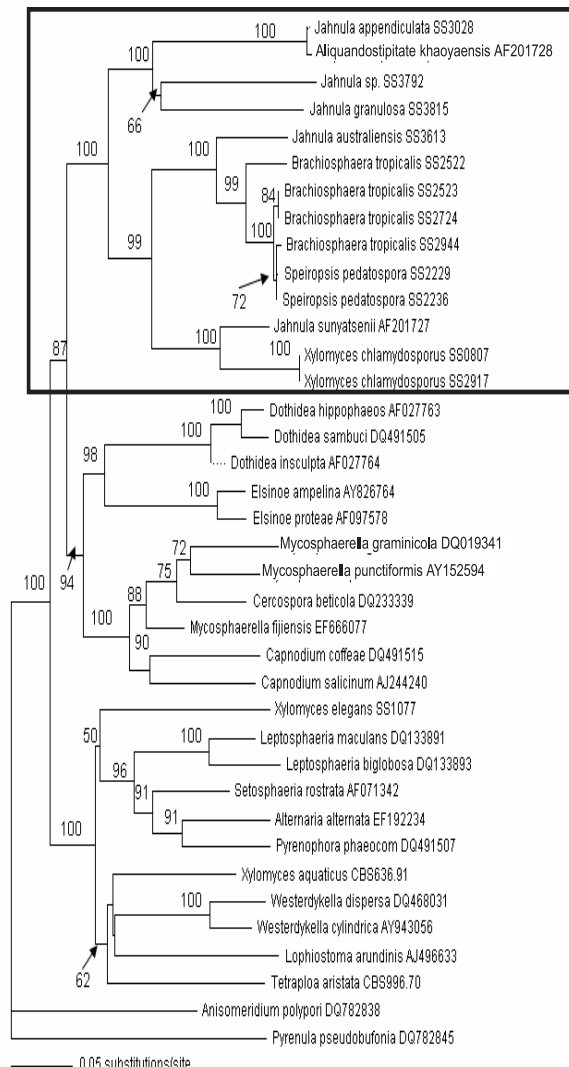

Jahnulales

Insertae sedis

Dothideomycetes

Dothideales

IMyriangiales

|

Capnodiales

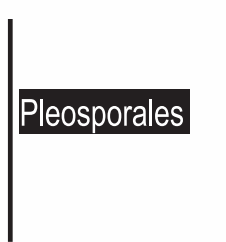

Dothideomycetidae

Pleosporomycetidae

Fig 2 Phylogenetics relationship of Speiropsis pedatospora, Xylomyces spp., Brachiosphaera tropicalis and Jahnula spp. based on ITS and $5.8 \mathrm{~S}$ rDNA sequences. The phylogram calculated on the neighbor joining analysis in PAUP* 4b10. Bootstrap support $>50 \%$ for neighbor joining trees were shown above the branches.
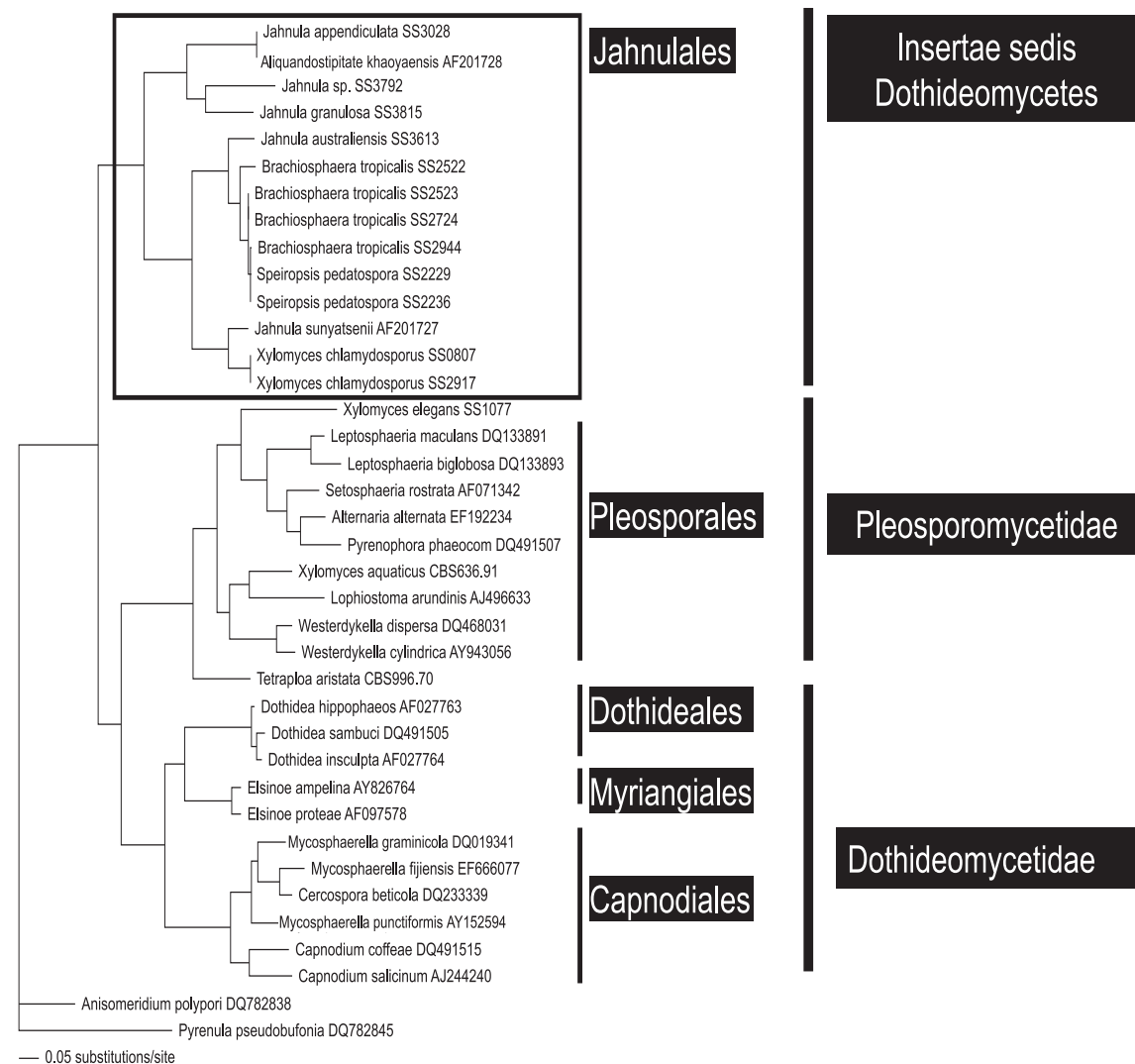

Pleosporomycetidae

\section{Dothideales}

Myriangiales

Capnodiales
Dothideomycetidae

Fig 3 Phylogenetics relationship of Speiropsis pedatospora, Xylomyces, Brachiosphaera tropicalis and Jahnula spp. based on ITS and 5.8S rDNA sequences. The phylogram calculated on the maximum likelihood analyses in PAUP* 4b10. The likelihood value $=-9229.03443$, base frequencies were estimated as follow: $\mathrm{A}=0.22546, \mathrm{C}=0.27760, \mathrm{G}=0.24967$ and $\mathrm{T}=0.24727$, the estimated value of the proportion as invariable sites $=0.225$, and the gamma shape parameter $=1.536$. The maximum likelihood analysis yielded a phylogeny with 2223 steps, CI $=0.466, \mathrm{RI}=0.661, \mathrm{RC}=0.307$ and $\mathrm{HI}=0.536$. 
$40 \mu \mathrm{m}$ wide, and ascospores composed of 2-cells or without appendages (Pang et al. 2002). The order comprised a single family, the Aliquandostipitaceae. Jahnulaes are widely distributed from temperate to tropical regions. Mostly the species of this order are to be found in freshwater habitats on lignicolous materials. This ecological name refers to their habitats being submerged wood (Pang et al. 2002; Raja and Shearer 2006).

Moreover, phylogeny analysis confirms that $S$. pedatospora is closely related to $B$. tropicalis, with strong boostrap support (98\%) and high posterior probabilities (76\%). The hyline conidia could be the apomorphic character, since both $S$. pedatospora and B. tropicalis possessed this morphology.

The phylogenies revealed that Xylomyces strains comprised a polyphyletic genus. Xylomyces chlamydosporus is placed in the Jahnulales while $X$. elegans and $X$. aquaticus are both accommodated in the Pleoporales. Even though the genus Xylomyces was created based on morphology and ontogeny (Goh et al. 1997), their phylogenies did not support that placement. This might result from convergent evolution among the Xylomyces species. Convergent evolution appears as a result of ecological equivalents. Since all Xylomeces share an aquatic habitat, this scheme indicates that chlamydospore-morphology in this genus results from adaptation to their habitat. Molecular phylogenetic studies also have confirmed the polyphyly of many anamorphic genera and species (Shenoy et al. 2007), such as Chalara (Paulin-Mahady et al. 2002), Galerina (Gulden et al. 2005) and Zopfiella (Cai et al. 2006).

Furthermore, Jahnulales has been divided into three subclades, each one with strong bootstrap support (>95\%). The first subclade is composed of $J$. appendiculata, $A$. khaoyaensis, Jahnula sp. SS3792 while J. granulosa, B. tropicalis and $S$. pedatospora are grouped in the second subclade. The third subclade is comprised of two species being $J$. sunyatsenii and X. chlamydosporus.

All of trees based on MP (unweighted and successive weighted parsimony), $\mathrm{NJ}$ and $\mathrm{ML}$ analyses showed similar topology. Those strains were placed in the three big clades, with clustering in the Jahnulales, Pleosporomycetidae and Dothideomycetidae. The NJ tree has a different branch pattern with MP and ML trees of the three big clades. The NJ tree showed Dothideomycetidae as a sister group of Insertae sedis Dothideomycetidae (Jahnulales), while in other trees, Dothideomycetidae appears as sister group of Pleoporomycetidae.

The phylogenic tree analyses obtained agrees with result of Schoch et al. (2006) that the Dothideomycetes was segregated into two subclasses comprised of the Dothideomycetidae (Dothideales, Myriangiales, Capnodiales) and the Pleosporomycetidae (Pleosporales). However several classes belonged to Insertae sedis Dothideomycetes. Based on these phylogenies, the Jahnulales is a sister group of either the Pleoporomycetidae or the Dothideomycetidae. We conclude that the Jahnulales was belongs to the Insertae sedis Dothideomycetes with a $100 \%$ bootstrap support and $100 \%$ posterior probability.

\section{ACKNOWLEDGEMENT}

This study was supported by the UNESCO Postgraduated Inter-University Course in Biotechnology 2006-2007 sponsored by Thailand Government and Japanese National Commission for UNESCO.

\section{REFERENCES}

Barbosa FF, Gusmao LFP. 2005. Two Speiropsis species (Anamorphic fungi-Hyphomycetes) from Bahia state, Brasil. Acta Bot Bras 19:515-518.

Cai L, Jeewon R, Hyde KD. 2006. Molecular systematic of Zopfiella and allied genera: evidence from multigene sequences analyses. Mycol Res 110:359-368.

Campbell J, Ferrer A, Raja HA, Sivichai S, Shearer CA. 2007. Phylogenetics relationship among taxa in the Jahnulales inferred from $18 \mathrm{~S}$ and $28 \mathrm{~S}$ nuclear ribosomal DNA sequences. Can J Bot $85: 873-882$.

Chang HS. 1994. Notes on genus Brachiosphaera from Taiwan. Bot Bull Acad Sin 35:125-127.

Farris JS. 1989. The retention index and the rescaled consistency index. Cladistics 5:417-419.

Goh TK, Ho WH, Hyde KD, Tsui KM. 1997. Four new species of Xylomyces from submerged wood. Mycol Res 101:1323-1328.

Gulden O, Stensrud O, Shalchian-Tabrizi K, Kauserud H. 2005. Galerina Earle: a polyphyletic genus in consortium of darkspored agarics. Mycologia 97:823-837.

Huelsenbeck JP, Ronqvist F. 2001. MrBayes: Bayesian inference of phylogeny. Bioinformatics 17:754-755.

Kishino H, Hasegawa M. 1989. Evaluation of the maximum likelihood estimate of the evolutionary tree topologies from DNA sequence data and the branching order of Homonidea. J Mol Evol 29:170179.

Pang KL, Abdel-Wahab MA, Sivichai S, El-Sharouney HM, Jones EBG. (2002). Jahnulales (Dothideomycetes, Ascomycota): A new order of lignicolous freshwater ascomycetes. Mycol Res 106:10311042 .

Paulin-Mahady AE, Harrington TC, McNew D. 2002. Phylogenetics and taxonomic evaluation of Chalara, Chalaropsis, and Thielaviopsis anamorphs associated with Ceratocystis. Mycologia 94:62-72.

Posada D, Crandall KA. 1998. Modeltest: testing the model of DNA substitution. Bioinformatics 14:817-818.

Raja HA, Shearer CA. 2006. Jahnula species from north and central America, including three new species. Mycologia 98:319-332.

Shenoy BD, Jeewon R, Hyde KD. 2007. Impact of DNA sequencedata on taxonomy of anamorphic fungal. Fungal Divers 26:1-54.

Schoch CL, Shoemaker RA, Seifert KA, Hambleton S, Sratafora JW, Crous PW. 2006. A multigene phylogeny of the Dothideomycetes using four nuclei loci. Mycologia 98:1041-105.

Swofford DL. 2002. Phylogenetics Analysis Using Parsimony (* and other method). Version 4. Sinauer Associates, Sunderland, Massachusetts.

Wang H, Meiqing Q, Cutler AJ. 1993. A simple method of preparing plant samples for PCR. Nucleic Acids Res 20:4153-4154.

White TJ, Bruns T, Lee S, Taylor J. 1990. Amplification and direct sequencing of fungal ribosomal RNA genes for phylogenetics. In: Innis MA, Gelfand DH, Sninsky JJ, White TJ (eds). PCR Protocols. San Diego. Academic Pr. p 315-322. 